\title{
Interrogating the Impact of Voluntary Asset and Income Declaration Scheme (VAIDS) on Tax Administration in Nigeria
}

\author{
Olise, Charles Nnamdi \\ Department Of Public Administration and Local Government, University of Nigeria \\ Nsukka \\ E-mail: charles.olise@unn.edu.ng \\ Emeh, Ikechukwu Eke \\ Department Of Public Administration and Local Government, University of Nigeria \\ Nsukka \\ E-mail: ikechukwu.emeh@unn.edu.ng
}

Received: May 26, 2020 Accepted: June 29, 2020 Online published: July 27, 2020

doi:10.5296/jpag.v10i3.17440 URL: https://doi.org/10.5296/jpag.v10i3.17440

\begin{abstract}
This paper examined the impact of the Federal government of Nigeria's tax amnesty programme tagged "Voluntary Asset and Income Declaration Scheme (VAIDS) on tax administration in Nigeria. This task is premised on the global reality of governments facing challenges funding developmental projects and other government paraphernalia due to paucity of funds as a result of tax evasions and tax avoidances. In most developing countries such as Nigeria, this tax evasions and avoidances have serious repercussion on the economic growth and development strides of the nation. To avert this menace, the federal government of Nigeria in line with some other countries of the world, created a tax amnesty window called Voluntary Assets and Income Declaration Schemes (VAIDS) to beat tax defaulters at their game and boost revenue generation towards generating the needed funds for developmental projects. For the purpose of this examination, data were generated through the secondary sources of data collection and analyzed with the content analysis. From the analysis, the paper found among others that VAIDS has impacted positively on revenue generation by expanding taxpayer's data base and also enhanced the identification of tax defaulters. However, poor adoption of information and communication technology (ICT) and
\end{abstract}


the inadequate publicity among others are the constraining factors to VAIDS achievement of its US $\$ 1$ bn target. Based on the findings, the paper recommends among others, proper institutionalization of ICT in data management for tax registration, assessment and collection processes and enforcing the penalties associated with not complying with VAIDS mercy window.

Keywords: VAIDS, tax amnesty, tax administration, tax evasion and avoidance, ICT

\section{Introduction}

Government expenditures (mostly) in the form of provision of basic infrastructure in any given country depends on the revenue generated by the government and one of the ways of generating adequate revenue is through well-structured tax system (Appah, 2014). As a dynamic subject associated with the constant changes in the economic environment in which it operates, taxation is an internal source of government revenue within the domestic economy of any nation upon which the development of any nation depends on as the number of infrastructural facilities provided for the common good of all, is a function of the amount of revenue generated through taxation (Azubike, 2009). The viability of tax as one of the major sources of revenue generation depends on the effectiveness of its administration. This is why tax administration is defined as the framework upon which tax system is based (Aguolu, 2004). It deals with the powers and duties of relevant tax authorities as contained in the tax laws and involves the procedures, principles and strategies adopted by any government in order to achieve effective tax planning, easy collection and proper accounting and utilization of the revenue collected (Appah and Oyadonghan, 2011; Appah, 2014).

While economic growth in any society depends on the provision of basic infrastructures (Fagbemi, Uadale and Noah, 2010), the provision of basic infrastructure and various social services to the people calls for adequacy of tax revenue and compliance to tax obligations. The laxity in tax administration in Nigeria has raised vital questions around the system of taxation and the possibility of enhanced economic growth and development through adequate provision of infrastructural facilities.

This is because revenue generation in Nigeria through taxation has been rated abysmal with minimal positive effects on the economic growth. Onakoya and Afintinni (2016) opined that the role of taxation in promoting economic growth in Nigeria is not fully felt, and optimal tax that can engineer economic growth is not been realized primarily because of their poor administration. Howbeit, Nigerian government has initiated various reforms to enhance the tax system, one of which is the tax reforms of 2004 which constitute an integral part of the National Economic Empowerment and Development Strategies. The national tax policy document was launched by President Goodluck Jonathan on April 7, 2012 with its essential component being the Integrated Tax Administration System (ITAS). The ITAS encompasses the project Joint Tax Board - Tax Identification Number (JTB-TIN) and also involves the deployment of the Standard Integrated Government Tax Administration Solution (SIGTAS) (Adeyeye, 2019).

In spite of the various tax laws and reforms by successive governments in Nigeria, the tax 
system has not yielded the desired result in terms of revenue generation. Adekunle, (2017) for example, asserted that in Nigeria's tax to GDP ratio at just $6 \%$, is one of the lowest in the world (compared to India's 16\%, Ghana's 15.9\%, and South Africa's 27\%). Most developed nations have tax to GDP ratios of between $32 \%$ and 35\%. In the same vein, the Joint Tax Board (JTB), document of May 2017 revealed that the total number of taxpayers in Nigeria is just 14 million out of an estimated 69.9 million who are economically active (Copley, 2017). This is as a result of revenue generation leakages courtesy of tax evasion and tax avoidance.

This has necessitated the adoption of different approach and compliance strategy to stop these revenue leakages and generate more revenue. One of such approaches is tax amnesty. Tax Amnesty could be traced back to August 1st, 2006, when the World Bank formally approved a Voluntary Disclosure Programme (VDP), which was an anti-corruption probing instrument designed to expose corrupt schemes and strengthen the institution's capacity to prevent corruption in its processes. The VDP permit cooperate organizations and individuals who have previously engaged in a fraud, to escape administrative punishments. It allows such entities the opportunity to disclose to the bank, all such prior misconducts and in addition to the satisfaction of specified terms and conditions, are exempted from public debarment for disclosed past misconduct and are assured of the bank's confidentiality (Ede, 2017).

In line with the promises of tax amnesty especially in keeping with the strategic game theory, the Nigerian government came up with tax amnesty for tax evaders tagged "Voluntary Assets and Income Declaration Scheme (VAIDS)" to grant pardon to all who voluntarily declare their tax liability during the allowed window of July 2017 to June 2018. Premised on this background, this study examined the outcome of the scheme in relation to enhanced tax administration in Nigeria.

\section{Conceptual Clarifications}

For enhanced comprehensibility, certain concepts used in this paper are clarified below.

\section{Tax, Taxation and Tax Administration}

Among the three main sources by which government raise revenue for the purposes of financing its expenditure, tax is a critical revenue source, comprising revenue received by the government from all available components of tax in a given country (Okafor, 2012). Modern tax is defined as a compulsory charge imposed by government on the income of individuals and companies as stipulated by the government decrees, acts or cases laws irrespective of the exact amount of services rendered to the payer in return. Hence, tax forms the key source of government revenue and the successes of every government in revenue generation and services delivery comes from the willingness of the citizens to execute their tax obligations in the absence of coercion and pestering.

Taxation is the concept, science and process of imposing tax on citizens. It is a compulsory levy required to be paid by every citizen, hence generally considered as a civic duty expected to yield income which should be utilized in the provision of amenities and creates conditions for the economic well-being of the society. The taxation imposed may be progressive, 
regressive or proportional. A progressive tax leads to increased tax rate as the amount of income increases while the opposite is the case with the regressive tax. In proportional tax, the effective tax rate is fixed notwithstanding the amount of income (Oseni, 2016).

Tax administration entails the holistic processes involved in the levying and collection of taxes imposed by constituted authorities. According to Bird (2015) a good tax system cannot produce excellent result without proper implementation. Proper implementation of tax system relied on tax administrators. The function of the tax administration revolves around scrutinizing compliance and also to enforce sanctions to offenders as provided in the rules and regulations (Bird, 2004). Effective tax administration heralds identification, assessment and collections of tax revenues (Gurawa and Mansor, 2015). The tax administration processes help to generate more revenue that helps governments to achieve greater financial reliance and facilitate the pursuit of growth-oriented structural adjustment (Owens, 2006).

\section{Voluntary Asset and Income Declaration Scheme (VAIDS)}

Tax Amnesty is not a novel concept. It has been adopted in more than 47 countries in the world including India, Indonesia, South Africa etc. and it has yielded positive benefits in all these countries (Cohen and Clark 2009; Perdiguez, 2019). Its primary objective is to encourage voluntary declaration of undisclosed incomes and assets with consequential payment of applicable tax liabilities over a defined period by companies and individuals. Taxes covered under the scheme include all taxes collectible by the Federal and State Inland Revenue Authorities; notably Companies Income Tax (CIT) Personal Income Tax (PIT), Petroleum Profits Tax (PPT), etc (Nangih, Idatoru and Kumah, 2016).

VAIDS is a time lag opportunity for taxpayers to normalize their tax status relating to previous tax periods. In exchange for fully and honestly declaring previously undisclosed assets and income, tax payers will be forgiven of their overdue interest and penalties, and they will not face criminal prosecution for tax offences or be subject to tax investigations. Therefore, VAIDS ushered in an opportunity to increase the nation's general tax awareness and compliance (Abiola cited in Nangih, Idatoru and Kumah, 2016) and by extension, provided an avenue to widen the tax net of the nation (Abiola, 2017).

\section{Methodology}

The study is a qualitative research. Data were generated from secondary sources. A content analysis approach was used to analyze the data generated. This method of analysis enabled for systematic review of extant literature on tax administration and economic growth in Nigeria in to order to ascertain the impact of VAIDS on Nigerian tax administration and economic growth.

\section{The Strategic Game Theory and Nigeria's Tax Amnesty (VAIDS)}

Despite finalizing the National Tax Policy, amending the tax laws and strengthening of the Federal Inland Revenue Service (FIRS) for enhanced operational efficiency, no real consideration was given to measures or strategies that may encourage voluntary declaration and compliance as an alternative means of growing the nation's tax base (Folarin, Arowolo, \& 
Olugbenro, n.d). These measures or strategies are fundamental and critical given the fact that tax evasion is a general problem to any country's tax administration. For some reasons, individuals and firms do fail to declare some of their taxes and the Nigerian tax administration is also made vulnerable by several factors, leading to revenue unwanted and unwarranted leakages that ought to be recouped. As a result, many governments have embraced tax amnesty. By implication, the embracing of tax amnesty and decision to evade tax are both strategic decisions by both players. Therefore, this study adopted the strategic game theory as its theoretical framework of analysis.

At its most basic level, game theory is the study of how people, companies or nations determine strategies in different situations in the face of competing strategies acted out by other agents or players. While it has been said that game theory is the study of strategic interactions between players, it is worthy to note that the key to understanding strategic decision making is to understand an opponent's point of view, and to deduce his or her likely responses to your actions. This is why it is said that game theory is not the study of how to win a game of chess or how to create a role-playing game scenario (Scheve, n.d.), but according to Nitisha (n.d.), in the game theory, different players adopt different types of strategies on the basis of the outcome, which is obtained by adopting the strategy. Therefore, game theory is the science of strategy, or at least the optimal decision-making of independent and competing actors in a strategic setting.

According to Scheve (n.d.), John von Neumann and Oskar Morgenstern introduced game theory to the world in 1943 with "Theory of games and Economic Behaviour." They hoped to find mathematical answers to economic problems.

Because in the game theory, different players adopt different types of strategies on the basis of the outcome, which is obtained by adopting the strategy, it is connected to the individuals or firm on one hand adopting strategies to evade tax for whatever reason, and the government adopting any strategy to recoup the unpaid taxes with both hoping to achieve outcomes.

While writing on the lessons from Nigeria's tax amnesty, Oyedele (2019) tried to explain why many people and firms in Nigeria seek to evade paying tax. According to him, the reasons are best inculcated into the definition of tax by the World Bank and PwC survey Paying Taxes, as any payment (whether or not it is called a tax) that has to be made to government without direct benefit or return of value, or provision of a service and so people are not persuaded in their heart to pay tax because there is no direct benefit or return of value.

However, apart from individual interest, there are many other reasons why tax evasion occurs. One central reason is poor system design - that is, the tax system that makes it very challenging to fulfill and conform to all tax obligations. For example, without VAT, many petty traders will not be able to conform even when they are ought to be legally. Additional causes of tax avoidance and evasion include the expensive nature of compliance, the vagueness of the tax rules, unawareness of those rules, the lack/poor punishment for previous non-compliance, dearth of public trust in government, and a failure to provide tax-funded social benefits and services (Oyedele, 2019). It is pertinent to note that tax evasion is not always an intended action, but can have unintended implications. 


\section{MInstitute ${ }_{\text {Mnk }}^{\text {Macrothink }}$}

Journal of Public Administration and Governance

ISSN 2161-7104

2020, Vol. 10, No. 3

The Nigerian Federal Inland Revenue Service (FIRS) and other States Board of Internal Revenue as its sub-unit are formal institution established with mandate of tax administration which involves: identification and registration of taxpayers, processing of tax returns and third-party information, examination of the completeness and correctness of tax returns, assessment of tax obligations, (enforced) collection of taxes and provision of services to taxpayers are aware of these facts which unfortunately, they do not have the way withal to change at least for now.

Given the low tax compliance, low level of income through tax and the risk associated with litigation, Nigeria launched a tax amnesty scheme in June 2017 that was designed to last for nine months, called the Voluntary Assets and Income Declaration Scheme (VAIDS) though later extended to 12 months. The programme sought to encourage the voluntary disclosure of previously undisclosed assets and income for all outstanding tax liabilities. The essence is to widen the tax net, thus raising much needed tax revenue now and in the future. Sadly, the revenue generated through the VAIDS platform fell far short of the US\$1bn target as only liabilities of US $\$ 268.3 \mathrm{~m}$ were declared, and payments received amounted to just US $\$ 103.3 \mathrm{~m}$, leaving US\$165m outstanding.

To show that it was a right step in the right direction, the Nigerian government in October 2018, introduced another tax amnesty called the Voluntary Offshore Assets Regularization Scheme (VOARS) for a 12-month period with the sole purpose of giving taxpayers with offshore assets the opportunity to declare them for tax purposes regardless of the legitimacy of the source. The critical thing about Nigeria's VAIDS tax amnesty and the strategic game theory is the fact that while critics sees VAIDS only with the lens of punish good taxpayer behaviour and reward lawbreakers, they forget that VAIDS did helped the Nigeria government to make up for a lack of tax authority capacity to audit all taxpayers, and generate significant tax revenue benefits to the tune of US\$103.3m. Moreover, even as Nigeria is still grappling with high levels of tax evasion, the rest of the world is moving the tax evasion and tax avoidance conversation on to tax morality, having utilized tax amnesty for a good number of times which translated into huge tax revenue and widen tax coverage which Nigeria needs. To us, this is a great game by the general government of Nigeria (Oyedele, 2019).

\section{The Effects of VAIDS on Tax Administration in Nigeria}

The assessment of VAIDS so far showed commendable achievements in the area of revenue generation, expansion of taxpayer's data base and indentifying tax defaulters even though the actual target of US\$1bn was not met. In terms of revenue generation, the former Director General of the Federal Inland Revenue Service Board, Mr. Babatunde Fowler explained that VAIDS which was designed to address the anomaly of 14 million out of 70 million economically active Nigerians, recorded tremendous success because while Nigeria made N4trillion revenue in 2017, an increase from N3.3trillion in 2016, she has collected N20billion out of the target N305billion from the Voluntary Asset Income Declaration Scheme (Proshare, 2018). 


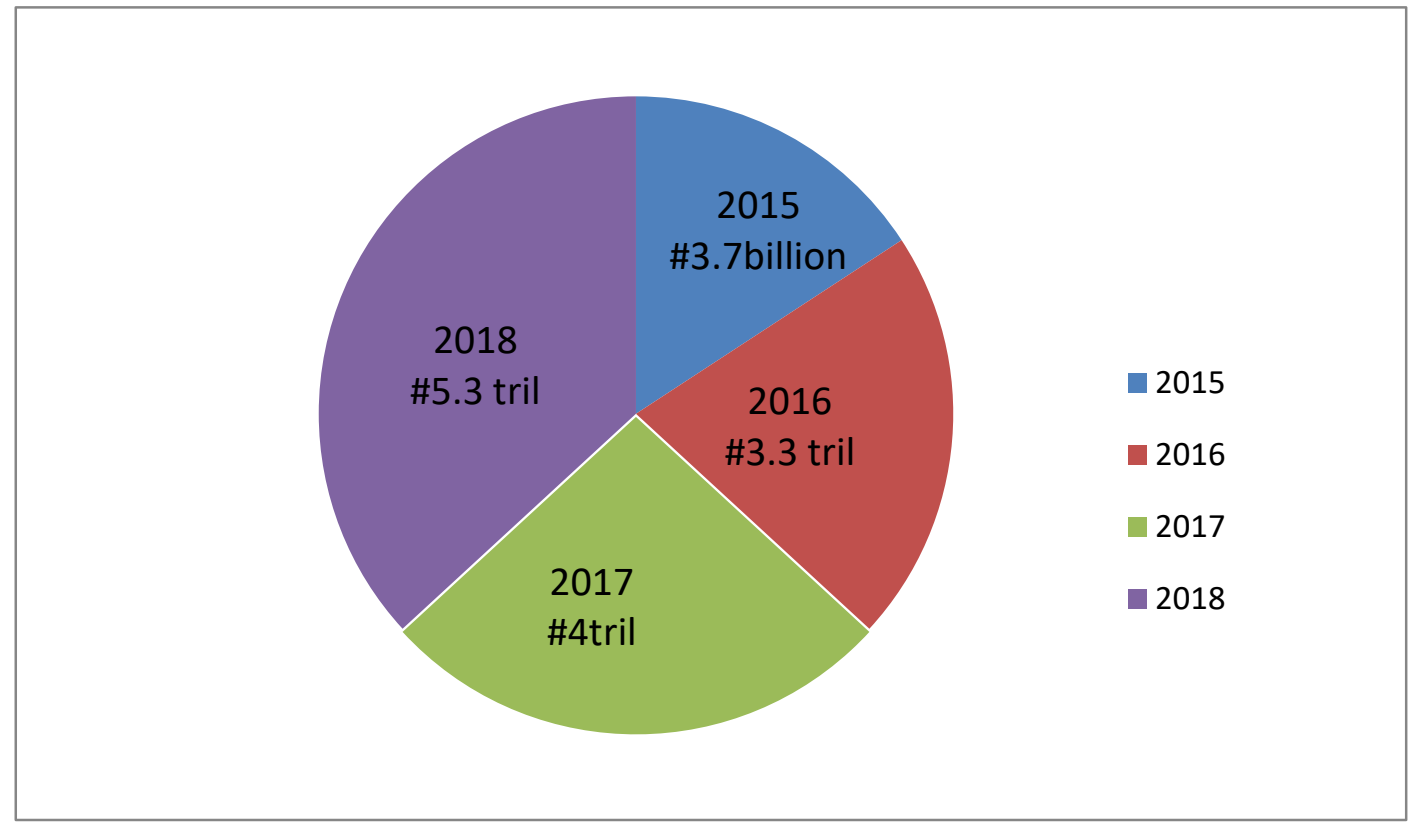

Figure1. Revenue Generation 2015 - 2018

Source: Gauge; a Quarterly Publication of FIRS (2018)

In terms of taxpayer's data base improvement, the former FIRS Boss explained that looking beyond the financial returns of the scheme, the impact it has had in promoting voluntary compliance is unquantifiable. But on the financial returns, VAIDS has increased the country's tax database from 14 to 19 million (Sahara Reporters, 2018). These numbers have translated into a positive growth in the country tax revenue-to-GDP ratio. He is optimistic that Nigeria's taxpayer roll will soon hit 45 million from 10 million in 2015 (The Cable, 2019).

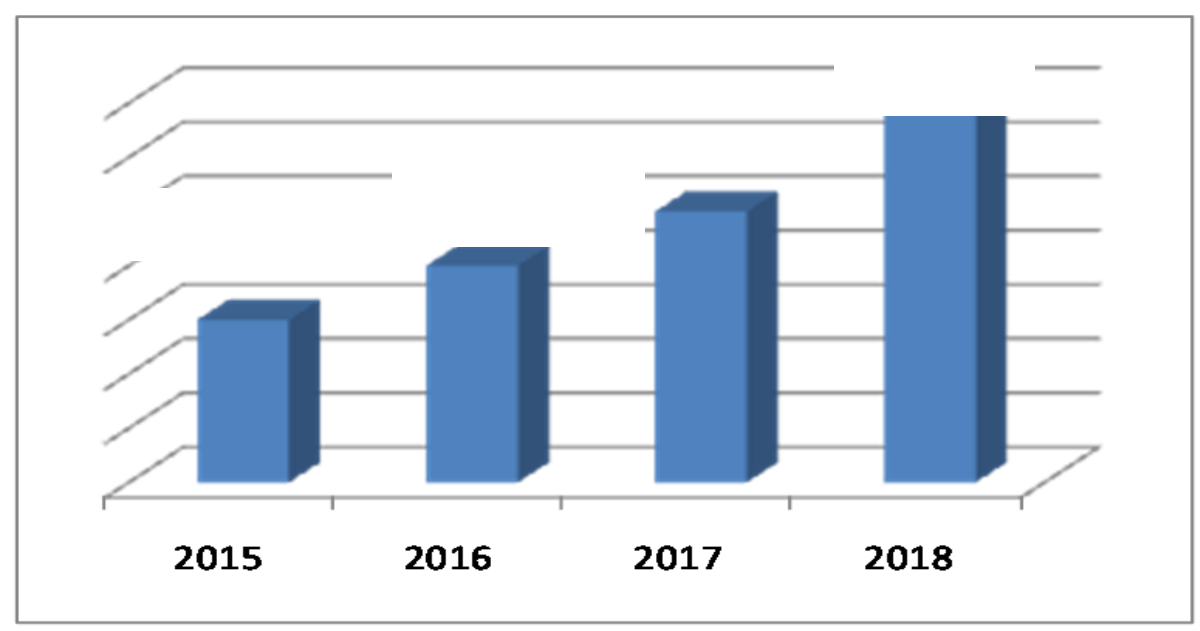

Figure 2. Tax payers' data base 2015-2018

Source: The cable (May 6, 2019). From 10m in 2015, Nigerian taxpayers 'soon to hit 45m'; Premium times (November 29, 2016). Nigeria taxpayers hit 13.4 million

Confirming the increase in number of taxpayers courtesy of VAIDS, the then Minister of 
Finance, Mrs. Kemi Adeosun stated that with VAIDS on track, all states of the federation now get more taxpayers in their tax net thus increasing their IGR. VAIDS has shown the potency to take the gains beyond the expectation (Chiejina, 2018). VAIDS goes beyond just taking advantage of immediate gains because in recent times, the incidence of illicit financial flows, aggressive tax avoidance and outright tax evasion are on the front burner" (Ndubuisi, 2018). It is also instructive to note that some local and foreign companies are now disposed to the VAIDS initiative, and have started to regularize their tax status. Thus, it does seem that its implementation has given further impetus to government to tackle unwholesome practices and abuses surrounding profit shifting (Tureta, 2018).

Assessment of tax and properties has been one of the major challenges of tax administration in Nigeria. This problem range from inability to exactly ascertain companies annual returns, partnerships, multiple properties, annual banking turnover, etc by the tax personnel. However, VAIDS has brought relieve this hitch. Obayomi, (2018) revealed that following the expiration of the amnesty window provided by the Voluntary Assets and Income Declaration Scheme (VAIDS), the FIRS is aware that some companies, partnerships and enterprises etc have annual banking turnover of N1 billion. VAIDS has exposed the transaction, income and assets on large number of Nigerians discovered from many sources such as land registries, banks, FIRS, Corporate Affairs Commission, Nigeria Customs Service, Federal Airports of Authority of Nigeria and numerous payment information platforms. Such data have been analyzed to yield tax debt profile (Ndubuisi, 2018).

The efforts to identify of tax defaulters by the FIRS and SIRS have been significantly enhanced by VAIDS. These defaulters, who are mostly high net-worth persons, were exposed via income, transaction, and assets information found from many sources. Following the identification process, the office communicated with them through nudge letters to call their attention to their defective tax status. The letters had yielded positive responses from the recipients, with many of them visiting or phoning the VAIDS office to request for more information on declaration and compliance (Olukoya, 2018).

The VAIDS office took data on all contracts and businesses more than N50 million from various agencies such as the Nigeria Customs Service, Asset Management Corporation of Nigeria and the Nigeria Export-Import Bank. Also data of over five million corporate organizations and individuals in the country have been collected through the VAIDS. The data collated was examined to unravel all unpaid taxes, trail and recover them. The analyses of the data would lead to substantial recapture of lost revenues and provide adequate data capture of eligible taxpayers (Naija247news.com, November 2, 2017).

VAIDS do not only target tax defrauders in Nigeria territory but has equally taken measures to track the Nigerians and properties beyond the national spheres, which are entitled to pay tax in Nigerian. According to Banwo \& Ighodalo (2017), Information available from the Ministry of Finance indicates that the FGN may have obtained important data of all economically active Nigerian citizens and residents, as well as Nigerians in the Diaspora.. More so, Nigeria has become a party to the Treaty on Automatic Exchange of Information (AEI) which has been signed by over 95 countries, for the global exchange of information on 
illicit financial flows and tax evasion.

\section{Challenges of VAIDS and Tax Administration in Nigeria}

In spite the achievements of VAIDS in terms of revenue generation, taxpayer's database expansion and so on, the scheme encountered some challenges which are discussed below.

\section{Inadequate ICT Adoption}

Tax administration in Nigeria has been beset with challenges, most of which can be attributed to the lack of or inadequate application of ICT in tax administration. Odusola cited in Adeyeye (2019) echoed that the system in Nigeria is lopsided. Tax officials in Nigeria have not adequately incorporated the use of IT in tax revenue collection and record keeping. Data of taxpayers' in the database of tax authorities are manually collected. This entails the use of files/ folders for data keeping. Access and retrieval of such data after a long period of time could be challenging. Adegbie and Fakile, (2011) equally opined that over the years, it is observed that income tax revenue has been grossly understated due to improper tax administration arising from under assessment and inefficient machinery for collection. The ineffective machinery still affected the VAIDS. The ineffective machinery which is manual process is expected to be overhauled by information and communication technology (ICT) as the reform (E-Payment scheme, Tax Identification Number (TIN) that promised automated tax system which regrettably has been not adequately felt.

\section{Low Public Sensitization and Awareness Creation}

One thing is to initiate a scheme or policy, another thing is to ensure that the scheme/policy gets to the public especially to the expected beneficiaries. Lack of awareness of the general public on the importance and benefits of taxation in Nigeria equally extended to VAIDS. Considering the fact that VAIDS was a time-limited scheme, it was unfortunate that many Nigerians that are tax defaulters who are expected to benefit from the scheme were not fully aware of the scheme and its benefits to them. The collaboration between JTB secretariat in with the Federal Ministry of Finance on every tax Thursday sensitization exercises and employment of 7500 community tax workers were commendable strategies by the FIRS but not enough to reach out to defaulters that are running in millions.

\section{Poor Social Service Provision}

Studies have revealed that many Nigerian's non-compliance attitude towards tax is as result of low or lack of benefits in terms of social services by the government. Despite the benefits of tax revenue to a country's economy, some citizens consider tax as undesirable levy imposed on them by government and accuse the government of not utilizing the tax revenue in a manner that achieves efficiency, economy and effectiveness of spending (Ekoja and Saratu cited in Oluyombo and Olayinka, 2018). This is evident in the complaints of many Nigerians shouldering the burden of social amenities. VAIDS is expected be an opportunity for tax offenders to make up for their previous offences of various forms and also re-establish the consciousness of the government to full their own part of responsibility.

\section{Policy Options/Recommendations}

Tax administration in Nigeria has been marred with tax avoidance and evasion. Despite the 
viability and potentiality of the VAIDS, if there are not concerted efforts to tackle these hurdles, the scheme may join the league of failed schemes and policies in Nigeria.

1. Enhanced use of ICT: Some of the tax reforms in Nigeria have created avenue for the use ICT to lift the tax administration from analog to automation. Taxpayers may not be required to visit the income tax office for tax compliance related matters if there is efficient and effective Information Technology System (ITS) in place. Regrettably, this has not transmitted in practice. Perhaps the poor commitment in the part of government in the procurement of necessary ICT facilities and low concerted efforts for human capital development has affected the adoption of ICT in the tax administration. Until ICT is adequately provided, the intents and desire to achieve effective tax administration in Nigeria will be a mirage.

2. Institutionalization of Tax Amnesty into tax administration in Nigeria: In spite of the extension of the period of the VAIDS tax amnesty, the lack of window internal definitely affected the intended objectives. Given the US\$165m outstanding of the US\$1 bn target, a reopening of the window period would have helped to get more money into the government treasury. Therefore, tax amnesty should be institutionalized in order to avail opportunities for defaulters that missed out in the previous amnesty window to make up for lost opportunity.

Improved Social Service Delivery by the Government: Many studies on Nigerian tax system revealed that tax non-compliance and apathy by the citizens occurs due to poor provision of basic social amenities by the government. In a situation where citizens' carter for their social amenities like water, light, security, roads, etc, zeal to pay taxes is at low ebb even with the introduction of the amnesty (VAIDS). To buttress this need for government to ensure social contract implementation, Obayomi, (2018) asserted "while the launching of VAIDS is an opportunity for tax payers in Nigeria to fulfil their past tax obligations, the government must also seize the opportunity to recommit itself to the social contract with its citizens so as to inspire their confidence and motivate voluntary tax compliance from now on". Thus, unless VAIDS is implemented to advance the mutual interest of both parties, it will not yield the intended result of promoting tax compliance culture and increasing the current tax of GDP ratio 6\%"far beyond.

\section{Collaborative Efforts with Foreign Nations/Agencies in Tracking Defaulters outside}

Nigeria: There is need for collaboration and synergy with foreign governments where assets and illicit funds are kept by Nigerians away from the scope of the taxing agency. The Nigerian federal government should leverage on various international agreements including the recently ratified Convention on Mutual Administrative Assistance in Tax Matters which has been signed by over 100 countries. This equally involves full involvement/engagement with the standard for Automatic Exchange of Financial Account Information in Tax Matters ("AEOI Standard) which is the international standard prescribed by the Organization for Economic Co-operation and Development (OECD) and the Global Forum on Transparency and Exchange of Information for Tax Purposes in the area of automatic exchange of information. 


\section{Conclusion}

Despite all the spelt out distinct penalties for different tax offences in tax reforms in Nigeria, tax payment as a compulsory civic obligation of all citizens within the taxable age has encountered several challenges. Many Nigerians who are paying their taxes diligently are those with white-collar jobs and it has been observed that they usually complain of the money deducted from their salaries and wages that are not enough to take care of their needs. This means that either they do not see tax as a civil obligation or they are not happy with the system that forces them to abide by this civic responsibility. By implication, they would not willingly pay their taxes if their taxes are not compulsorily deducted from source. To those in businesses, they will do anything to avoid tax payment or evade it. These citizens assume it a game they have to play to beat the government from collecting taxes from them, but because these tax evasion and avoidance that have persisted overtime have fundamental revenue generation and invariably economic growth draw backs in Nigeria, the federal government also device a means to beat the citizens who avoid or evade taxpaying in their game. Thus, the federal government introduced a tax amnesty window that waves every liability from tax defaulters so long as they (the tax defaulters) come up and disclose their tax indebtedness and clear them minimally. The programme was termed Voluntary Assets and Income Declaration Scheme (VAIDS). This tax amnesty programme (VAIDS) has proven to be a pivotal strategy not only to generate more revenue but also ensures effective tax administration in terms of identifying defaulters, proper registration, assessment, collection, etc. However the potency, the VAIDS should be accompanied by government improvement in the provision of social services in order to revive the dead conscience and apathy of the citizens towards voluntarily tax compliance so that Nigeria can move away from tax amnesty discussion to tax morality as other big economies have done. This approach can be a winner game played at the higher level where citizens will be happy to abandon their game of recovering from government's bad governance through tax avoidance and evasion. Hence, unless VAIDS is implemented to advance the mutual interest of both parties, it will not yield the intended result of promoting tax compliance culture and increasing the current tax of GDP ratio 6\%"far beyond.

\section{References}

Abata, M. A. (2014). The Impact of Tax Revenue on Nigerian Economy: Case of Federal Board of Inland Revenue. Journal of Policy and Development Studies, 9(1), 109-121. https://doi.org/10.12816/0011186

Abdullahi, S. R., \& kuwata, G. (2016). The Problem of personal income tax generation and administration. International journal of Innovative Research in Information Security, 1(2), 117.

Abdurrahman, A. P., \& Muzainah, B. M. (2016). A modernize tax administration model for revenue generation. International Journal of Economics and Financial Issues, 6(7), 192-196.

Adekunle, A. (June 7, 2017) VAIDS Aimed at Correcting Nigerian's Poor Tax to GDP Ratio Finance Minister. Retrieved on 25/5.2020 from https://www.vanguardngr.com/2017/07/vaids-aimed-correcting-nigerias-poor-tax-gdp-ratio-fi 
nance-minister/

Adeyemi, K. S. (2012). Sustainable Development Strategies for Poverty Alleviation: the tax perspective. Paper delivered at the annual tax conference of the chartered institute of taxation of Nigeria, Nicon Luxury Hotel, Abuja, 10th May 2012.

Adeyeye, G. B. (2019). Improving tax administration through technology innovation in Nigeria: A Study of Federal Inland Revenue Service."Annals of SpiruHaret University. Economic Series, 19(1), 31-63. https://doi.org/10.26458/1913

Aguolu, O. (2004). Taxation and tax management in Nigeria. Enugu: Meridian Associates.

Akinpelu, D. (February 2, 2018). VAIDS Office Writes Tax Defaulters. Retrieved on 25/5/2020 from https://punchng.com/vaids-office-writes-tax-defaulters/

Appah, E. (2014). Principles and Practice of Nigerian Taxation. Lagos: Andy Best Publishers.

Appah, E., \& Oyadongha, J. K. (2011). The challenges of tax mobilization and management in the Nigerian economy", Journal of Business Administration and Management, 6(2) 128-136.

Babatunde, O. A., Ibukun, A. O., \& Oyeyemi, O. G. (2017).Taxation Revenue and Economic Growth in Africa. Journal of Accounting and Taxation, 9(2), 11-22. https://doi.org/10.5897/JAT2016.0236

Banwo \& Ighodalo Chambers (2017). The Last Days of VAIDS: Why Taxpayers Should Take Advantage of The Amnesty Programme. Retrieved from https://www.banwo-ighodalo.com/assets/grey matter/4547f23a1a872ef1b4e18f92ec70c945.pdf on 20/5/2020

Bird, R. M. (2015). Improving Tax Administration in Developing Countries. Journal of Tax Administration, 1(1), 23-44.

Chiejina, N. (June 8, 2018). Benefits of VAIDS. Retrieved from https://thenationonlineng.net/benefits-of-vaids/ on 12/4/2020

Chigbu, E. E., \& Njoku, C. O. (2015). Taxation and the Nigerian Economy: (1994-2012). Management Studies and Economic Systems), 2(2), 111-128. https://doi.org/10.12816/0019397

Cohen, S., \& Clark, J. (23 December 2009). Italy's Tax Amnesty Brings in \$114 Billion. Retrieved on 25/5/2020 from www.wsj.com.

Copley, A. (June 30, 2017). Nigeria aims to bolster tax revenues through amnesty program. Retrieved on $21 / 5 / 2020$ from https://www.brookings.edu/blog/africa-in-focus/2017/06/30/africa-in-the-news-audit revealsdepth-of-mozambiques-debt-nigeria-launches-tax-amnesty-program-and ethiopian-airlines grows-its-fleet-2/ 


\section{Macrothink}

Journal of Public Administration and Governance

ISSN 2161-7104

2020, Vol. 10, No. 3

Edame, G. E., \& Okoi, W. W. (2014). The impact of taxation on investment and economic development in Nigeria. Academic Journal of Interdisciplinary Studies, 3(4) 209-218. https://doi.org/10.5901/ajis.2014.v3n4p209

Ede, C. I. (2017). Nigerian Tax System and Expectations of VAIDS. CITN Education, Research and Technical Publication, October 2017.

Fagbemi, T. O., Uadale, M., \& Noah, A. O. (2010). The ethics of tax evasion, perceptual evidence from Nigeria. European Journal of Social Sciences, 17(31), 112-145.

Folarin, F., Arowolo, S., \& Olugbenro, Y. (nd). Amnesty for Tax Defaulters: How viable for voluntary tax compliance in Nigeria? Retrieved on 3/3/2020 from https://www2.deloitte.com/ng/en/pages/tax/articles/inside-tax-articles/amnesty-for-tax-default ers.html

Garba, L. S. (2014). Tax Revenue and Economic Growth in Nigeria. (Unpublished Thesis). Zaria: Ahmadu Bello University.

Gauge (October - December, 2018). N5.3 Trillion: FIRS makes highest collection in nation's history. $\quad$ Retrieved on 20/3/2020 from https://www.firs.gov.ng/sites/Authoring/contentLibrary/GAUGE\%204th\%20QUARTER\%20 2018.pdf

Igbara, N., Nangih, E., \& Akpeekon, B. (2017). International financial reporting standards adoption and financial disclosures of SMEs, evidence from Port Harcourt Metropolis in Nigeria. International journal of business and finance management research, 5(2), 1-6.

Jakir, K. (2011). Role of Tax revenue in Economic Development. Journal of Accounting and Tax revenue, 2(4), 45-63.

Naija247news.com (November 2, 2017). VAIDS tracks 5m corporate organizations in tax compliance drive. Retrieved on from https://naija247news.com/2017/11/02/vaids-tracks-5m-corporate-organizations-in-tax-compli ance-drive/

Nangih, E., Idatoru, A. R., \& Kumah, L. J. (2018).Voluntary Assets and Income Declaration Scheme (VAIDS) Implementation in Nigeria: A Case of an 'Executive Order' with Many Faces. Journal of Accounting and Financial Management, 4(6), 1-13.

Ndubuisi, F. (June 18, 2018). VAIDS: Lessons to Learn from Tax Amnesty. Retrieved on $23 / 4 / 2020$

from https://www.thisdaylive.com/index.php/2018/06/18/vaids-lessons-to-learn-from-tax-amnesty/

Nitisha (n.d.). 4 Strategies of the Game Theory - Explained! https://www.economicsdiscussion.net/game-theory/4-strategies-of-the-game-theory-explained 13825

Obayomi, W. (2018) Nigeria's Voluntary Assets and Income Declaration Scheme and $\begin{array}{lllll}\text { Responsible } & \text { Tax. } & \text { Retrieved } & \text { on } & \text { 23/3/2020 }\end{array}$ 
https://responsibletax.kpmg.com/page/nigeria-s-voluntary-assets-and-income-declaration-sch eme-and-responsible-tax

Obayomi, W. (2018). VAIDS - Clarification to Taxpayers with Annual Turnover of N1 Billion. Retrieved on 23/3/2020 from https://home.kpmg/ng/en/home/insights/2018/07/VAIDS-Clarification-to-Taxpayers-with-An nual-Turnover-of-N1Billion.html

Ogbonna, G. N., \& Appah, E. (2016) Effect of Tax Administration and Revenue on Economic Growth in Nigeria. Research Journal of Finance and Accounting, 7(13), 1-10.

Okafor, R. G. (2012), Tax revenue generation and Nigerian economic development. European Journal of Business and Management, 4(19), 1905-1922.

Oluyombo, O. O., \& Olayinka, O. M. (2018).Tax Compliance and Government Revenue Growth in Nigeria. Lapai International Journal of Administration, 1(2), 245-253.

Onakoya, A. B., \& Afintinni, O. I. (2016) Taxation and Economic Growth in Nigeria. Asian $\begin{array}{llll}\text { Journal of } \quad \text { Economic } & \text { 199-210. }\end{array}$ https://doi.org/10.18488/journal.8/2016.4.4/8.4.199.210

Onwuchekwa, J. C., \& Aruwa, S. A. S. (2014). Value Added Tax and Economic Growth in Nigeria. European Journal of Accounting Auditing and Finance Research, 2(8), 62-69.

Oyedele, T. (01 June 2019). Nigeria's tax amnesty lessons: Insights. Retrieved on 20/05/2020 from

https://www.accaglobal.com/an/en/member/member/accounting-business/2019/06/insights/ta x-amnesty.html

Perdiguez, V. (2019). "Expand Your Visions. Discover the Treasures". CPADavao.com. Retrieved 2020-05-22.

Premium times (November 29, 2016). Nigeria taxpayers hit 13.4 million. Retrieved from https://www.premiumtimesng.com/news/top-news/216644-nigeria-taxpayers-hit-13-4-million .html on $14 / 05 / 2020$

Proshare (February 21, 2018). VAIDS: We have collected N20bn out of the target N305bn Tunde Fowler. $\quad$ Retrieved on $22 / 4 / 2020$ from https://www.proshareng.com/news/Taxes\%20\&\%20Tariffs/VAIDS--We-have-collected-N20b n-out-of-the-target-N305bn---Tunde-Fowler/38571

Proshare (June 30, 2017). Executive Order on the Voluntary Assets and Income Declaration Scheme (VAIDS). Retrieved on 20/3/20202 from https://www.proshareng.com/news/Taxes\%20\&\%20Tariffs/Executive-Order-on-the Voluntary-Assets-and-Income-Declaration-Scheme--VAIDS-/35342

Romer, C. D., \& Romer, D. H. (2010). The Macroeconomic Effects of Tax Changes: Estimates Based on a New Measure of Fiscal Shocks. The American Economic Review, 1(2), 763-801. https://doi.org/10.1257/aer.100.3.763 


\section{Macrothink}

Journal of Public Administration and Governance ISSN 2161-7104 2020, Vol. 10, No. 3

Sahara Reporter $\left(7^{\text {th }}\right.$ June2018). FG's VAIDS Has Raised The Country's Tax Database From 14 To 19 Million, Says FIRS Boss. Retrieved on 20/4/2020 from http://saharareporters.com/2018/06/07/fgs-vaids-has-raised-countrys-tax-database-14-19-mill ion-says-firs-boss

Sanni, A. (2017). Understanding VAIDS: The legal framework. Lecture delivered at Training Workshop by the Ministry of Finance at Nicon Luxury, Abuja on 9 November 2017.

Scheve, T. (nd). How Game Theory Works. Retrieved on 22/5/2020 from https://science.howstuffworks.com/game-theory.htm

Takumah, W. (2014). Tax Revenue and Economic Growth in Ghana: A Cointegration Approach. MPRA Paper No. 58532. Retrieved from https://mpra.ub.uni-muenchen.de/58532/

The cable (May 6, 2019). From 10m in 2015, Nigerian taxpayers 'soon to hit $45 \mathrm{~m}$. https://www.thecable.ng/just-in-from-10m-in-2015-taxpayers-about-to-hit-45m Retrieved on $30 / 04 / 2020$

Tureta, S. (June 2, 2018). Nigeria: VAIDS- the Changing Dynamics of a Tax Amnesty. Retrieved on 23/3/2020 from https://allafrica.com/stories/201806020122.html

Udo, B. (June 29, 2017) Nigerian Government to Grant Amnesty to Defaulting Voluntary Tax Payers. Retrieved on 21/1/2020 from https://www.premiumtimesng.com/news/headlines/235372-nigerian-govt-grant-amnesty-defa ulting-voluntary-tax-payers.html

\section{Copyright Disclaimer}

Copyright for this article is retained by the author(s), with first publication rights granted to the journal.

This is an open-access article distributed under the terms and conditions of the Creative Commons Attribution license (http://creativecommons.org/licenses/by/4.0/). 